\title{
Employee Fringe Benefits in Employer Bankruptcy
}

The federal Bankruptcy Act provides uniform procedures for liquidating and distributing the available assets of any business that is unable to pay its debts. ${ }^{1}$ While these procedures generally involve both an equitable distribution of assets among creditors and the bankrupt's subsequent discharge from his debt burden, for policy reasons some claims are given priority over others, and certain of those are not discharged. ${ }^{2}$ Under section 64(a)(2) the unpaid wage claims of workers, clerks, servants, and salesmen have a priority and are not dischargeable; they are paid out of available unsecured assets directly after expenses for administering the estate and before any payment to general creditors, tax collectors, or landlords. ${ }^{3}$ The priority covers wages earned within three months of bankruptcy and is limited to $\$ 600$ per claimant. ${ }^{4}$

This priority status for wage claims was originally established in 1898,5 when compensation in the form of fringe benefits, such as vacation pay and health insurance, was unknown. ${ }^{6}$ In the early cases,

1 Bankruptcy Act, ch. 541, § I et seq., 30 Stat. 544 (1898), as amended 11 U.S.C. § : et seq. (1970) [hereinafter cited as NBA].

2 See NBA $\S$ 17, 64, 11 U.S.C. $\S \S 35,104$ (1970). On the policies of bankruptcy legislation generally, see REPORT OF THE COMMISSION ON THE BANRRUPTCY LAWS OF THE UNITED States, pt. I, at 61-84 (1973); D. Stanley \& M. Girth, Bankruptcy: Problems, Process, AND REFORM (1971) [hereinafter cited as STANLEY \& GrRTH]; Levi \& Moore, Bankruptcy and Reorganization: A Survey of Changes (pts. I \& II), 5 U. CHI. L. REv. 1, 219 (1937).

3 The section provides: "(a) The debts to have priority, in advance of the payment of dividends to creditors, and to be paid in full out of bankrupt estates, and the order of payment, shall be ... (2) wages and commissions, not to exceed $\$ 600$ to each claimant, which have been earned within three months before the date of the commencement of the proceeding, due to workmen, servants, clerks, or traveling, or city salesmen on salary or commission basis, whole or part time, whether or not selling exclusively for the bankrupt ...." NBA § 64(a)(2), II U.S.C. § 104(a)(2) (1970). This section applies to straight bankruptcy proceedings, railroad reorganizations, farm debt relief, and arrangement proceedings. Section 64 does not apply to Chapter $X$ reorganization proceedings unless the administering court enters an order that it apply. One instance in which such an order was entered is the case of In re Wil-low Cafeterias, Inc., III F.2d 429 (2d Cir. 1940). The Act provides that section 64(a)(2) claims are not discharged by bankruptcy. NBA \$ 17(5), 11 U.S.C. § $35(5)(1970)$.

4 Id.

5 Act of July 1, 1898, ch. 541, \& I et seq., 30 Stat. 544 (1898).

6 Fringe benefits that pass from employer to employee take many forms. They are generally understood to be compensation for services rendered, just like more traditional wages. Some fringe benefits may be gifts, but most are the result of arms-length bargaining between employer and employee. To the limited extent that gift transactions occur, they are irrelevant to this comment, because promissory gifts do not usually create an en- 
therefore, priorities were granted to claims for sums owing on the daily wage. In recent years, however, employee claims have largely been for fringe benefits, ${ }^{7}$ and the courts have had to determine whether such claims are entitled to section 64(a)(2) priority.

In two cases the Supreme Court has held that priority is not proper where funds are owed to trustees and the employees' eventual receipt of the funds either is dependent on future events or is to occur only in the distant future. ${ }^{8}$ The Court has indicated that it believes the purpose of the statute is to relieve the immediate hardship of the workers and has based its denials of priority on holdings that the funds were not "due to" the workers under the terms of the statute nor "wages" of the type that must be paid to satisfy the relief purposes of the statute. Several lower courts, in opinions between and after the two Supreme Court opinions, have held in very similar fact situations that priority is proper. The lower courts have ignored the Supreme Court opinions or distinguished them as applying only where the funds are due in the remote future or where trustees are claiming the funds. ${ }^{\circ}$ The reluctance of the lower courts to follow the rule that seems to emerge from the Court's decisions ${ }^{10}$ may be due in part to the arbitrary distinctions and obscurities inherent in that rule, but it most probably is based on the fact that the purpose stated by the Court as the basis for its rulerelief of immediate hardship-makes no sense where the average period between initiation of bankruptcy proceedings and distribution of assets is at least two years. ${ }^{11}$

This comment first explores the rule that has emerged from the

forceable claim against the donor. Restatement of Contracts $\$ 90$ (1932). Fringe benefits given with the understanding that the benefit will terminate with termination of employment, such as use of an employees' swimming pool, or a salesman's car, cannot give rise to claims under section 64(a)(2). Benefits involving monetary payments from the employer, such as pension fund contributions, vacation pay, holiday pay, and severance pay, are the source of contention in bankruptcy proceedings. Generally these payments take one of two forms. Either the employer holds the money until the employee is to receive it, or periodic payments are made to a trust fund which then makes payments to the employees at the appropriate time.

7 This may be attributed in part to changes in business practice-employers must regularly meet their payrolls in order to survive, so that wages are generally paid up at bankruptcy-and in part to the fact that labor now actively seeks fringe benefits as part of the compensation scheme.

8 United States v. Embassy Restaurant, Inc., 359 U.S. 29 (1959); Joint Industry Board v. United States, 391 U.S. 224 (1968).

- See cases cited at notes 22 \& 23 infra.

10 See text at notes $30-41$ infra.

11 The study discussed in STANLEY \& GIRTH, supra note 2, concludes: "For business cases in our sample the average (mean) time from the filing of the petition until closing was more than twenty-three months. ..." Id. at 131. If any assets were available for distribution, the length of time between filing and closing increased. Id. at 132. 
decisions of the Supreme Court and demonstrates its deficiencies. It then inquires into the purposes underlying the grant of priority in order to develop a coherent rule for deciding whether fringe benefits should receive priority as "wages" under section $64(a)(2)$.

\section{The State of the Law}

\section{A. Case Law on Priority for Fringe Benefits}

The Supreme Court first confronted the issue of priority for fringe benefits in United States $v$. Embassy Restaurant, Inc. ${ }^{12}$ In that case the bankrupt employer was bound by collective bargaining agreements to contribute $\$ 8$ per month per full-time employee to the trustees of a union welfare fund. The welfare plans were organized to obtain "life insurance, weekly sick benefits, hospital and surgical benefits," and other advantages for members of the local unions. These benefits were payable to employees only upon future contingencies such as death, illness, or disability. By the terms of the trust agreement, workers could not sell or assign their benefits. In the bankruptcy proceedings, the trustees of the fund asked that section 64(a)(2) priority be given the funds. This claim was disallowed by the referee, ${ }^{13}$ but on review was granted by both the trial court ${ }^{14}$ and the Court of Appeals, ${ }^{15}$ which reasoned that the benefits obtained with the funds were in effect additional wages. ${ }^{16}$ The Supreme Court reinstated the ruling of the referee.

The Court concluded that "the contributions here are not 'due to workmen,' nor have they the customary attributes of wages."17 In reaching this conclusion the Court emphasized that:

Trustees administered each plan under a formal trust agreement and were authorized to formulate and establish conditions of eligibility for benefits, control all the funds received, collect all contributions, and in their "sole discretion" to handle all legal proceedings incident thereto. Title to all the funds, property, and income was placed in the trustees exclusively .... ${ }^{18}$

The Court dismissed as irrelevant the fact that "unions bargain for these contributions as though they were wages."19 The Court stated,

12359 U.S. 29 (1959).

13 Bankruptcy judges were called bankruptcy referees at the time these cases were decided.

14154 F. Supp. 141 (E.D. Pa. 1957).

15254 F.2d 475 (3d Cir. 1958).

16 Id. at 477 .

17 United States v. Embassy Restaurant, Inc., 359 U.S. 29, 33 (1959).

18 Id. at 30.

$19 \mathrm{Id}$. at 33 . 
however, that although the contributions were not "due to workmen" nor possessed of the customary attributes of wages, priority could be granted if it was clear that the contributions satisfied "the purpose for which Congress established the priority." 20 The Court viewed the priority as being intended "to enable employees displaced by bankruptcy to secure, with some promptness, the money directly due to them in back wages, and thus to alleviate in some degree the hardship that unemployment usually brings to workers and their families."21 Thus in this case priority could not be granted; since workers could only receive money from the trust fund if they died or were disabled-that is, on future contingencies - the claimed payments could not satisfy the congressional purpose of relieving immediate hardship.

Subsequent to Embassy Restaurant, lower courts and referees found priority where no trust fund was involved, ${ }^{22}$ such as with vacation pay, and where the payments were to be held by the trustees for only a limited period of time after which right to the sums vested in the employees regardless of intervening events. ${ }^{23}$ The next Supreme Court opinion, Joint Industry Board $v$. United States, ${ }^{24}$ did little to clarify the status of claims for these types of payments.

In Joint Industry Board, trustees of a union pension fund, which provided benefits similar to those provided by the Embassy welfare fund, claimed priority for unpaid employer contributions to the fund. Unlike Embassy, the trust agreement provided that benefit payments would at minimum return to the employee the total of the contributions credited to his name, regardless of whether the employee left his job before the contingencies entitling him to greater payments occurred. Further, an employee could receive benefits upon leaving the industry as well as upon death, retirement, or disability. ${ }^{25}$ Despite these differences the Court concluded that Embassy Restaurant controlled. ${ }^{26}$ The Court held that the claims did not have the "customary attributes of wages," because they were payable only to the trustees, who had the exclusive right to hold and manage the fund. Though the contributions were credited to individual employee accounts, nothing was payable to em-

$20 I d$.

21 Id. at 32 .

22 Straus-Duparquet, Inc. v. Local 3, IBEW, 386 F.2d 649 (2d Cir. 1967) (vacation and severance pay); In re Ad Service Engraving Co., 338 F.2d 41 (6th Cir. 1964) (vacation and severance pay); In re Mergentime, Inc., 217 F. Supp. 887 (S.D.N.Y. 1963) (vacation pay); In re Wolfe Creation, Inc., BANKR. L. REP. If 63,272 (E.D.N.Y. 1969) (vacation pay); In re Troymake Corp., BANKR. L. REP. If 63,014 (N.D.N.Y. 1968) (vacation pay).

23 Sulmeyer v. Southern Cal. Pipe Trades Trust Fund, 301 F.2d 768 (9th Cir. 1962) (vacation and holiday pay).

24391 U.S. 224 (1968).

$25 \mathrm{Id}$. at 226.

$26 I d$. 
ployees except upon the occurrence of certain events. ${ }^{27}$ Further, under the fund agreement, employees could not assign their benefits. ${ }^{28}$ The Court also relied on the finding that priority for these funds would not satisfy the purpose of section 64(a)(2); because employees would receive the funds claimed only on the occurrence of certain contingencies that did not include employer bankruptcy, priority would not provide prompt alleviation of the hardship caused by unemployment. ${ }^{29}$

\section{B. The Uncertain Rule}

The two Supreme Court cases seem to suggest that two requirements must be met for fringe benefits to qualify for priority. The first requirement is that the fringe benefit at issue have the "customary attributes of wages." ${ }^{30}$ The second is that priority relieve immediate hardship arising from unemployment caused by the employer's bankruptcy. ${ }^{31}$ In reality, these two requirements are probably one; that is, a fringe benefit has the "customary attributes of wages" if and only if the worker has a sufficient legal interest in the fund to allow him to use it for immediate relief during unemployment. ${ }^{32}$ This rule would seem to continue to allow priority to claims for sums due directly to workers at the end of a fixed period, such as vacation pay, and several lower courts, avoiding both Embassy Restaurant and Joint Industry Board, have so held. ${ }^{33}$ It would also seem to allow priority for sums due to trustees for transfer at an early date to employees. ${ }^{34}$

The basic problem with the Supreme Court's rule is that it simply is not realistic to believe that in the present system, priority will "enable

$27 \mathrm{Id}$. at 227.

28 Id. at 227 n.3.

$29 I d$. at $227-28$.

30 See text and notes at notes $17 \& 27$ supra.

31 See text and notes at notes $20 \& 29$ supra.

32 The cases could also be read as establishing a rule based on the identity of the person to whom the funds claimed were payable ("due to")-in these cases to trustees rather than workers. Aside from being a highly formalistic reading of the statute, such an interpretation would base recovery entirely on adroit draftsmanship in employment contracts and trust fund agreements. See 3A W. Collier, BaNkruptcy I 64.202[1] n.I (1972); 48 VA. L. REv. 1308, 1312 (1962).

33 In In re S.E.S. Meat Co., Inc., BANkER. L. REP. I 64,668 (S.D.N.Y. 1972) (severance pay), and In re Erie Forge Steel Corp., BANKER. L. REP. I 63,581 (W.D. Pa. 1970) (vacation pay), the courts based their grant of priority on early vacation pay cases without mentioning Embassy Restaurant or Joint Industry Board. The cases cited at note 22 supra likewise failed to distinguish Embassy Restaurant when they granted priority to vacation pay and severance pay that was paid directly to workers.

34 The Ninth Gircuit granted priority for a vacation pay trust fund on the authority of Sulmeyer v. Southern Cal. Pipe Trades Trust Fund, 301 F.2d 768 (9th Cir. 1962), without distingüishing Joint Industry Board. Bowman v. Bay Area Painter's Trust Fund, 447 F.2d 1106 (9th Cir.), cert. denied, 404 U.S. 995 (1971). 
employees displaced by bankruptcy to secure, with some promptness, the money directly due to them ... and thus to alleviate in some degree the hardship that unemployment usually brings to workers and their families." 35 In the present system, the mean time between filing of the bankruptcy petition and distribution of assets is two years. ${ }^{36}$

If workers could assign their claims against the bankrupt estate they could, of course, realize their claim before distribution of assets and thus obtain immediate relief. Since 1906 it has been established that assignment of a priority wage claim does not impair the priority status. In Shropshire, Woodliff, of Co. v. Bush ${ }^{37}$ the Supreme Court held that "[w] hen one has incurred a debt for wages due to workmen ... that debt ... is entitled to priority .... The character of the debts was fixed when they were incurred, and could not be changed by an assignment." 38 In Embassy Restaurant, the Supreme Court commended this holding as providing a means whereby employees could realize their claims before the closing of the bankruptcy proceedings. ${ }^{39}$ In practice, however, this avenue of relief is closed because there is no market for workers' claims. Assignees are unwilling to buy workers' claims because of uncertainty as to the amount that will ultimately be available for distribution.40 Thus, there is no practical way that section $64(\mathrm{a})(2)$ can provide immediate relief. ${ }^{41}$

\section{A Reinterpretation of Section 64(a)(2)}

Relief of immediate hardship, the legislative purpose that the courts have invoked in construing section 64(a)(2), has been shown to be inapplicable in the context of the current bankruptcy system. Congress's recent re-enactment $t^{42}$ of the priority, however, indicates an intent that

35 United States v. Embassy Restaurant, Inc., 359 U.S. 29, 32 (1959).

36 See note Il supra.

37204 U.S. 186 (1907).

38 Id. at 189.

39359 U.S. 29, 34 (1959).

40 Conversations with Soia Mentschikoff, Professor of Law, and David Epstein, Visiting Professor of Law, The University of Chicago Law School, 1974. See StanLey \& GirTH, supra note 2, at $129 \& 132$. They found that priority creditors received on the average 36 percent of amounts proved and allowed. The length of time between filing and recovery ranged from twelve to over forty-eight months. The combination of the 36 percent chance of recovery and the uncertainty as to the time of recovery makes these claims unmarketable.

11 Of course, this does not mean that an unemployed worker is without help from his government. Unemployment compensation schemes are extensive. See IB UNEMPL. INS. REP. $\$ 3001$ (1967).

42 Act of November 28, 1967, 81 Stat. 511 (1967). Section 64(a) was re-enacted with amendments to subsection $64(2)(1)$. The Supreme Court recognized this as a re-affirmation of subsection 64(a)(2). Joint Industry Board v. United States, 391 U.S. 224, 228 (1968). 
it continue to have significance in the bankruptcy system. Other policies that might lie behind Congress's enactment and preservation of the priority must therefore be examined. The dominant policy that emerges from this examination is that of favoring the general economic interests of a certain class of workers. If section 64(a)(2) is to serve this purpose, it should be construed to embrace claims for regular wages but not fringe benefits.

\section{A. Reassessing the Purposes of the Priority}

Although the legislative histories of the original Bankruptcy Act and subsequent amendments contain no discussion of section $64(a)(2),{ }^{43}$ the terms of the act themselves suggest an intention to favor generally a special class of workers, who have great economic need and poor bargaining position, by increasing their ultimate prospects of recovery as well as alleviating the immediate hardship of their unemployment. ${ }^{44}$

1. The Nondischargeability of Section 64(a)(2) Debts. Section 17(5) ${ }^{45}$ excepts section 64(a)(2) claims from the dischargeability provisions that apply to almost all other claims. ${ }^{46}$ This shows a clear intent to favor the workers' uItimate prospects of recovery over the essence of the bankruptcy system-allowing the bankrupt to start a new life unburdened by his earlier mistakes.

2. The Income Level of Workers Protected by the Priority. From the descriptions of the classes of workers in section 64(a)(2) itself, it is apparent the congressional concern was focused on low income workers. The priority is available only to "workmen, servants, clerks or traveling, or city salesmen"47 - "persons of menial position and low income" 48 - whose earnings, when the Act was passed,49 probably were sufficient only for day-to-day necessities. For these employees to lose payment for their labor meant the loss of the ability to maintain even a minimally decent standard of living. ${ }^{50}$ Employees to whom losing pay-

43 Act of July 1, 1898, ch. 541 \& 1 et seq., 30 Stat. 544 (1898); Act of May 27, 1926, ch. 406 \& 15, 44 Stat. 666 (1926) (raising maximum allowable claim to $\$ 600$ ); Act of June 22 , 1938, ch. 575, \& 64, 52 Stat. 874 (1938) (re-ordering priorities within section 64); Act of July 30,1956 , ch. 784, 70 Stat. 725 (1956) (clarifying status of salesmen).

44 See 3A W. Colcier, supra note 32, at I 64.201[3] n.7. The Bankruptcy Act favors other classes because of their weak economic positions. For example, involuntary bankruptcy cannot be imposed upon persons who earn less than $\$ 1500$ per year or upon farmers. NBA § 4(b), 11 U.S.C. § 22(b) (1970).

45 NBA § 17(5), II U.S.C. § $35(5)$ (1970).

46 NBA \& 17,11 U.S.C. $\S 35$ (1970).

47 NBA § 64(a)(2), 11 U.S.C. § 104(a)(2) (1970).

48 In re Paradise Catering Corp., 36 F. Supp. 974, 975 (S.D.N.Y. 1941).

49 Act of July 1, 1898, ch. 541 \& 1 et seq., 30 Stat. 544 (1898).

50 E.g., In re Guerwitz, 121 F. 982, 983 (2d Cir. 1903) (intended for "those who have 
ment for their labor meant only a reduction in amenities and conveniences were excluded.51 For example, in 1915 a general manager earning $\$ 300$ per month was denied priority in the same case in which priority was granted to a shop foreman who also had supervisory duties. ${ }^{52}$ The shop foreman, however, earned only $\$ 150$ per month. ${ }^{53}$ The courts have long recognized the social and moral judgment this classification represents. "The Iaborer," one court noted in 1930, "is generally dependent upon his wages for livelihood and the support of his family .... Every consideration of morality, as well as public policy, demands, therefore, that his wages be preserved to him and be given priority over ordinary commercial claims." 54

Even though the current duration of bankruptcy proceedings ${ }^{\mathrm{55}}$ precludes viewing the priority as a means of providing subsistence itself, the presumption remains that the favored class of workers can seldom use their income for nonessentials. In discussing a laborer's personal bankruptcy, the Eighth Circuit recently observed that "the fact that a low income wage earner must forego the immediate enjoyment and use of all his earnings because of the withholding of a part for tax purposes does not change his continuing need to spend all his funds on hand for personal and family sustenance whenever those funds become available."

3. The Inability of Workers to Foresee Bankruptcy. Early judicial interpretations of the section found a legislative concern with not only the harsh results of bankruptcy for the laborer, but also the unfairness of his suffering for ignorance of his employer's chances of going bankrupt. ${ }^{57}$ "The statute," Judge Learned Hand wrote, "was intended to

served ... in a subordinate or menial capacity and who are supposed to be dependent upon their earnings for their present support."); Manly v. Hood, 37 F.2d 212, 213 (4th Cir. 1930) (intended for those "dependent upon [their] wages for livelihood and the support of [their] famil[ies]"); In re Caldwell, 164 F. 515, 516 (E.D. Ark. 1908) (intended "to protect those who are dependent on their daily earnings for their support"). See also $3 \mathrm{~A}$

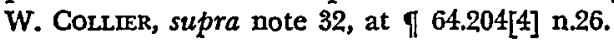

51 Frasher v. Robinson, 458 F.2d 492 (9th Cir. 1972) (general manager of business); In re Paradise Catering Corp., 36 F. Supp. 974 (S.D.N.Y. 1941) (actress earning $\$ 400$ per week); In re Estey, 6 F. Supp. 570 (S.D.N.Y. 1934) (teacher); In re Lawsam Electric Co., 300 F. 736 (S.D.N.Y. 1924) (chief designer); In re All Star Feature Corp., 231 F. 251 (S.D.N.Y. 1916) (actress earning $\$ 5000$ per month). Contra, In re New England Thread, 158 F. 788 (1st Cir. 1907) (salesman earning $\$ 4000$ per year). See also 3A W. ColturR, supra note 32 , at $\{64.204[4] \mathrm{n} .26$.

62 Blessing v. Blanchard, 223 F. 35 (9th Cir. 1915).

53 Id. at 37.

54 Manly v. Hood, 37 F.2d 212, 213-14 (4th Cir. 1930).

55 See note 11 supra.

56 Gehrig v. Shreves, 491 F.2d 668, 672 (8th Cir. 1974).

67 Manly v. Hood, 37 F.2d 212 (4th Cir. 1930); In re Lawsam Electric Co., 300 F. 736 (S.D.N.Y. 1924). 
favor those who could not be expected to know anything of the credit of their employer, but must accept a job as it comes." 58 The priority favors that class of laborers least likely to have or understand information about the employer's economic health.

\section{B. The Contemporary Meaning of Section 64(a)(2)}

Increasing the general prospects, rather than the immediacy, of recovery of an especially deserving class of claimants appears to be the element of the original purpose that remains viable. It might be argued that this goal is best satisfied by granting priority to all fringe benefits. The rationale for this step would be that fringe benefits are as much expected and bargained-for income as are wages. ${ }^{59}$ The Commission on Bankruptcy Laws, which issued its report in July, 1973, adopted this view. ${ }^{60}$ A fair evaluation of congressional intent, however, indicates that construing section $64(a)$ (2) to cover fringe benefits does not satisfy the intent to aid a class that can "ill-afford to be classified as general creditors." 61

1. Structuring the Priority to Favor the Ultimate Recovery of the Target Class. Paid vacations, pensions, and severance pay are rewards for accepting lower wages at the time they are earned. ${ }^{62}$ Employees who receive such benefits have bargained for automatic savings plans in exchange for lower regular wages. Employees who can afford to defer compensation are not within the class-"those who are supposed to be dependent on their earnings for their present support"63 - that Congress intended to protect when it enacted section 64(a)(2). Proposals that reject this interpretation of section 64(a)(2) and recommend priority for all fringe benefits because "union negotiators agree to smaller direct wages in exchange for greater fringe benefits"64 overlook the fact that employees can accept this exchange only if their income is sufficiently above subsistence level.

A grant of priority for fringe benefits does not merely strike a new balance between conventional creditors and the employees to whom

58 In re Lawsam Electric Co., 300 F. 736 (S.D.N.Y. 1924).

59 United States v. Embassy Restaurant, Inc., 359 U.S. 29, 33 (1959): "It is contended, however, that since 'unions bargain for these contributions as though they were wages' and industry likewișe considers them 'as an integral part of the wage package,' they must in law be considered 'wages."

60 RePort of the Commission on the BANkRUPtcy LAws, supra note 2, at 215.

61 In re Paradise Catering Corp., 36 F. Supp. 974, 975 (S.D.N.X. 1941).

62 "The payments are certainly not gifts." United States v. Embassy Restaurant, Inc., 359 U.S. 29, 37 (1959) (Black, J., dissenting).

63 In re Guerwitz, 121 F. 982, 983 (2d Cir. 1903).

64 United States v. Embassy Restaurant, Inc., 359 U.S. 29, 33 (1959). 
the benefits are owed. If fringe benefits are granted priority, the 64(a)(2) recovery of lower-paid workers who have no such benefits would be reduced in some bankruptcies-in flat contradiction to the purpose of the statute. If, for example, the fund to be distributed is sufficient to pay 75 percent of every eligible employee's claim, the "fringe" increment of some employees' claims might be satisfied before the regular wage claims of other employees. ${ }^{65}$

Increases in the general standard of living and the unionization of many industries have brought many workers covered by the technical statutory language to a wage level where they can afford to take their payments as fringe benefits; the categories Congress devised for identifying the class of persons it intended to aid have grown obsolete. To satisfy the legislative purpose of favoring ultimate recovery by a certain class, courts must look to other elements of the statute for workable limitations. The "customary attributes of wages" language provides such a limitation. Limiting the priority to regular wages-compensation made available for discretionary spending by the employee as he completes units of work-would effectively, though not literally, confine the benefits to the workers Congress wanted to reach. ${ }^{66}$

2. Incidental Effects of the "Regular Wages" Interpretation. The "regular wages" construction of section 64(a)(2) would permit some distributions to employees not within the class intended to be favored because employees who receive fringe benefits would still receive priority for their regular wage claims. Recovery by those workers, however, would not significantly frustrate the aims of the statute. The limitation of claims to the previous three months' wages, not to exceed $\$ 600,67$ assures that the regular wage claims of better-paid employees will not consume an excessive portion of the funds available for distribution.

65 For example, a business employs two categories of workers, one which receives only a weekly wage of $\$ 150$ per week and one which receives $\$ 150$ per week plus the equivalent of $\$ 15$ per week in fringe benefits. At bankruptcy, the first group is owed two weeks' wages, or $\$ 300$, and the second is also owed two weeks' regular wages, $\$ 300$, plus an accumulation of two months' fringe benefits, $\$ 120$, for a total of $\$ 420$. If all section $64(a)$ (2) claims are paid at 75 percent, the group earning only the weekly wage will receive $\$ 225$ while the group receiving both the weekly wage and the fringe benefits would receive $\$ 315$.

The proposal of the Commission on the Bankruptcy Laws partially eliminates this problem by establishing two priorities-one for sums due directly to workers and one for sums due to trustees on behalf of workers. The problem partially remains, however, because some fringe benefits are explicity included in the first priority. REPORT OF THE COMMISSION ON the BankRUptcy Laws, pt. II, p. 110 (1973).

60 The proposal would overturn the extension of section $64(a)(2)$ already made by lower courts in vacation and severance pay cases. See note 22 supra.

67 NBA \& 64(a)(2), 11 U.S.C. \& 104(a)(2) (1970). For the text of the section, see note 3 supra. 
3. Alternative Methods of Restricting the Priority to the Target Class. The alternatives are to exclude completely from section 64(a)(2) priority either all employees who receive fringe benefits or the employees who receive fringe benefits and others whose earnings are comparable. The first alternative would require an interpretation too inventive to be reconciled with the statute's facially unambiguous description of the classes of employees to be benefitted. More important, it would treat equally employees with comprehensive fringe benefits and those with nominal ones. In contrast, allowing regular wage claims by both these groups would permit the latter, presumably lower-paid employees, to recover a larger percentage of their total claim. ${ }^{68}$ The first alternative would also cause employees who are at the same income level but receive their compensation in different forms to be treated unequally. Fringe benefit recipients would be excluded from the priority, but employees receiving economically indistinguishable compensation would be included.

The second alternative, although attractive in light of the legislative purpose, requires an even heavier gloss on the statute than the first alternative. Section $64(\mathrm{a})(2)$ cannot be read to permit a judicially created income cutoff beyond which the job descriptions in the statute have no application. Until Congress sees fit to substitute more responsive criteria for the categories currently used in the section, occasional unintended results must be tolerated out of respect for legislative prerogatives.

\section{Policy Considerations Beyond Section 64(a)(2)}

The more general policies of the Bankruptcy Act also deserve consideration. General creditors are affected by the interpretation placed on section $64(\mathrm{a})(2)$. The special equity of the claims of workers who qualify for the priority is based on their need for payment at least up to basic subsistence level. Fringe benefit claims are in many ways not distinguishable from other debts of the bankrupt, and basic principles of equity suggest that all claims against the bankrupt be treated alike. ${ }^{69}$

The bankrupt's interests must also be considered. Perhaps the most compelling policy underlying the liquidation chapters of the Act is to forgive the bankrupt's obligations so that he can begin a new financial

68 The exclusion of the employee who is only slightly better off than the employee receiving only regular wages might seem arbitrary. $A$ line must be drawn, however, and the distinction between regular wages and fringe benefits is an administrable one.

69 "The broad purpose of the Bankruptcy Act is to bring about an equitable distribution of the bankrupt's estate . . . Kothe v. R. C. Taylor Trust, 280 U.S. 224, 227 (1930). See also 3A W. Collier, supra note 32, at I 64.02[6]. 
life. ${ }^{70}$ This policy is based on Congress's perception that the investment of risk capital has beneficial effects beyond the satisfaction of those who buy the production such investment yields. ${ }^{11}$ Public subsidy of those who undertake to begin new enterprises after a bankruptcy is appropriate. Broadening the coverage of section $64(a)(2)$ reduces that subsidy, because the debts that have this priority are nondischargeable. ${ }^{72}$ Of course, if the bankrupt is a corporation, liquidation and dissolution of the corporate entity, in effect, discharge all unpaid wage claims under the authority of state corporation acts. ${ }^{73}$ Fringe benefit claims are not crucial to employees, but cumulatively these debts create a substantial burden for a noncorporate bankrupt attempting to finance a new business. All the creditors of the new enterprise would be inferior in priority to the nondischarged claims, and would adjust accordingly the price of the capital and materials they provide. To the extent that broadening the priority dampens the incentive for investment of risk capital, inclusion of fringe benefits within section 64(a)(2) reduces the availability of jobs. Thus, the very class of creditors that would be expected to profit from enlargement of the priority might be significantly prejudiced.

\section{Conclusion}

In order to resolve the present ambiguities in the interpretation of section $64(a)(2)$, the courts should limit coverage of the statute to regular wages, excluding all fringe benefits. The current inclusion of some fringe benefits is undesirable and without foundation in the purpose of the priority. Limiting section $64(\mathrm{a})$ (2) to regular wages has the effect, consistent with legislative purpose, of providing a bright line test for restricting the section's benefits to the class of workers in special need of protection.

Ann Rae Heitland

70 See Levi \& Moore, supra note 2.

71 NBA § 17, 11 U.S.C. § 35 (1970).

72 Id.

73 See, e.g., Business Corporation Act § 23, I InL. Rev. Stat. ch. 32, § 157.23 (1973). 